\title{
Socio-Economic Characterization of Local Guinea Fowl (Numida meleagris) Populations in three Agro-Ecological Zones of Burkina Faso
}

\author{
Kalo Amadou Ouattara ${ }^{1 *}$, Ollo Cherubin Hien ${ }^{2}$, Issa Dao ${ }^{1}$, Gaston Marie Adrien Belem ${ }^{1}$ \\ ${ }^{1}$ Department of Breeding, IDR, University Nazi Boni 01 BP 1091 Bobo-Dioulasso 01, Burkina Faso \\ ${ }^{2}$ INERA, Farako-Ba, 01BP 910 Bobo-Dioulasso 01, Burkina Faso
}

*Address for Correspondence: Mr. Kalo Amadou Ouattara, Student, Department of Breeding, IDR, University Nazi Boni 01 BP 1091 Bobo-Dioulasso 01, Burkina Faso

E-mail: kalo amadou@yahoo.fr

Received: 24 Jul 2018/ Revised: 15 Nov 2018/ Accepted: 26 Feb 2019

\begin{abstract}
Background: The guinea fowl (Numida meleagris) is widespread in Burkina Faso in a traditional system, where it is bred in freedom. The objective of this study was to characterize, at the socioeconomic level, local populations of guinea fowl at three agro-economic zones.

Methods: The study was conducted in three agro-ecological zones (Sahelian zone, northern Sudan zone, and southern Sudan zone) of Burkina Faso. To do this, 120 breeders due to 40 breeders per zone were the subject of socioeconomic surveys.

Results: The results shown that training in poultry farming and schooling of livestock farmers were higher in the south $160 \%$ and $43 \%$ ) than in the north and the Sahel. In guinea fowl management, women's participation was higher in the north than in the two zones (southern and Sahel) where the participation of children and men was high. In the Sahel, production was primarily intended for self-consumption and donations (75\%), while in the north and south it is heavily used for breeding and sales (60\%). The average price of guinea fowl and egg was higher in the south (3000 and 75 FCFA), followed by that of the Sahel (2500 and 60 FCFA) and the north (2200 and 50 FCFA). The major constraints were health problems and brutal deaths in the south, north and sahel (60\%).

Conclusion: It emerges from the study that in the Sahel the social aspect is important, in the north; the activity was more monetarized while in the south the self-consumption is remarkable.
\end{abstract}

Key-words: Burkina Faso, Characterization, Guinea fowl, Numida meleagris, Socioeconomic

\section{INTRODUCTION}

Food for African populations remains deficient in animal protein despite the increase in ruminant production in African countries and the massive importation of meat [1]. Faced with this challenge, governments were encouraging the development of production of shortcycle animals, namely poultry ${ }^{[2]}$. Burkina Faso produces around thirty (30) million head of poultry a year. In poultry farming, the breeding component of guinea fowl is particularly important ${ }^{[1]}$.

\section{How to cite this article}

Ouattara KA, Hien OC, Dao I, Belem GMA. Socio-Economic Characterization of Local Guinea Fowl (Numida meleagris) Populations in three Agro-Ecological Zones of Burkina Faso. SSR Inst. Int. J. Life Sci., 2019; 5(2): 2235-2243.

Access this article online
https://iijls.com/

The guinea fowl ( $N$. meleagris) was a species highly appreciated for its meat and eggs in West Africa ${ }^{[3]}$. Its breeding occupies a place of choice, given its socioeconomic importance (rites, sacrifices, donations), nutritional in the lives of the populations ${ }^{[4]}$ and is a source of income for the communities ${ }^{[5]}$. Despite these various forces, the development of local guinea fowl farming is hampered by the low productivity of animals reared in an extensive rambling system ${ }^{[6]}$. However, improved breeding conditions could increase the productivity of local guinea fowl ${ }^{[6-8]}$.

The general objective was to understand the socioeconomic characteristics of the local populations of guinea fowl (N. meleagris) of the Sahel, South Sudanian and North Sudanian ecotypes of Burkina Faso in order to guide decision-making in development programs of Guinea Fowl Farming in Burkina Faso. 


\section{MATERIALS AND METHODS}

Site of the study- The study was conducted in three agro-ecological zones (Sahelian zone, northern Sudan zone, and southern Sudan zone) of Burkina Faso among the four cited by Seydou ${ }^{[9]}$. The choice of areas had been made taking into account the importance of raising guinea fowl in the regions of the mentioned areas. Agro-ecological zoning is shown in Fig. 1.

The Sahelian zone is located in the extreme north of Burkina Faso. It covers an area of $36.166 \mathrm{~km}^{2}$ or $13.3 \%$ of the national territory. It is a region characterized by low rainfall ( $\leq 400 \mathrm{~mm}$ ). In this area, the data were collected in the province of Seno.
The northern Sudanian zone, The North Sudanese zone has an average annual rainfall of between $700 \mathrm{~mm}$ and $900 \mathrm{~mm}$. Its temperature varies between $22.7^{\circ} \mathrm{C}$ and $35.4^{\circ} \mathrm{C}$. In this area, data were collected in the Central West region in Boulkiemde province.

The southern Sudanian zone, the annual rainfall of this zone is between $900 \mathrm{~mm}$ and $1200 \mathrm{~mm}$. The average temperature is $27^{\circ} \mathrm{C}$. In this area, data were collected in the Hauts-Bassins region in the Houet and Kenedougou provinces.

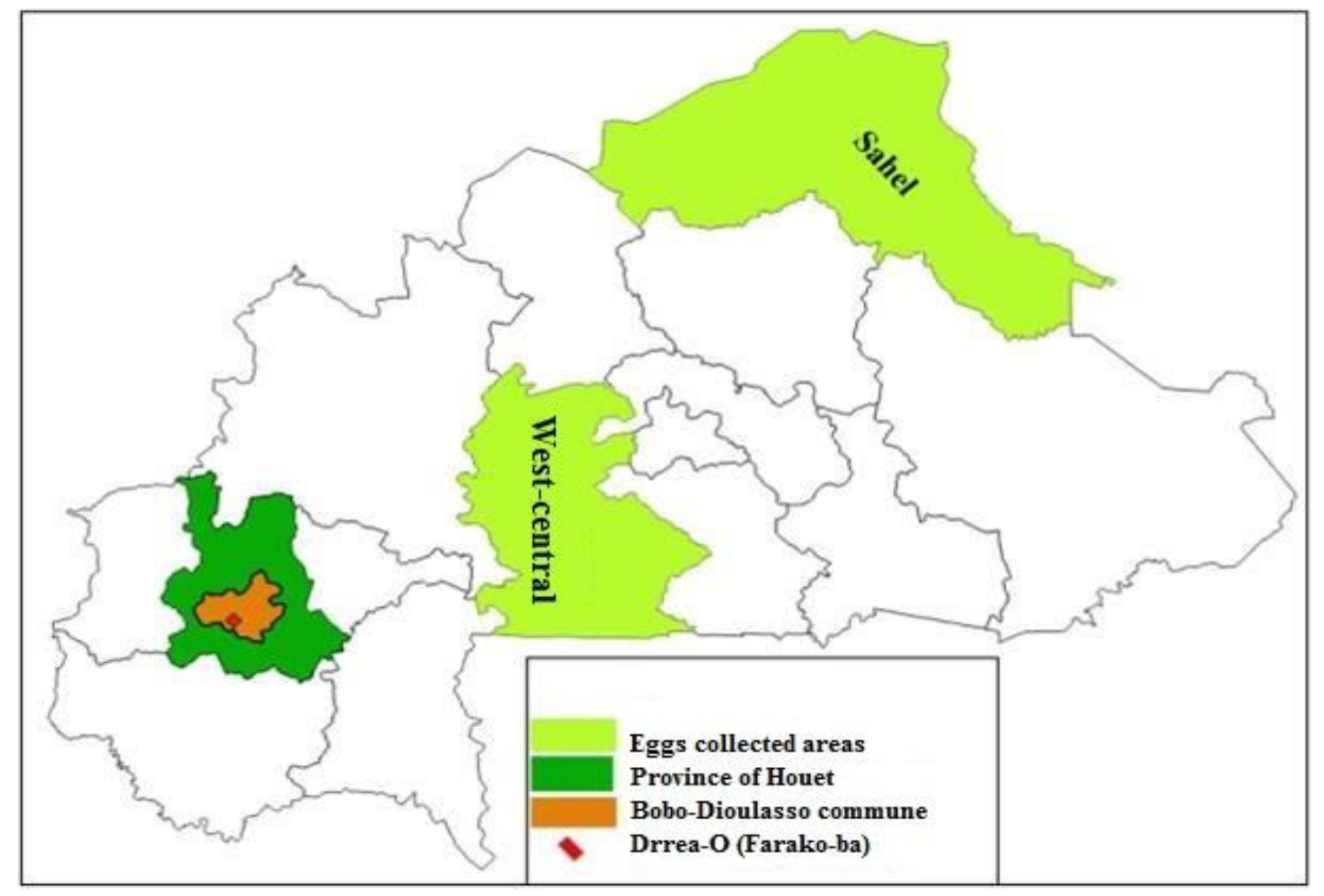

Fig. 1: Data-gathering areas in Burkina Faso

Collection of data and sampling- The collection of data was realized at August 2017 to December 2017. We used the random sampling method for the choice of farmers. Indeed, it was done by a semi-structured survey. Producers must have at least one year of experience and be between 15 and 80 years old. In each area, a small proportion of women practising Guinea Fowl farming were selected. In each agro-ecological zone, 40 breeders or a total of 120 breeders were interviewed about information relating to the socio-economic characterization of the guinea fowl, namely the production objectives, the role played by each family member, the reasons for the samples taken and proportions of use of guinea fowl and its eggs, the constraints related to Guinea Fowl farming.

Statistical Analysis- For data processing, a database was created using the Sphinx 4 software and then transferred to the IBM SPSS statistics.20 software and the Microsoft Excel 2013 spreadsheet. The data analyzes (qualitative and quantitative) were done with the XIstat 2007 software. Between the nominal qualitative data, the analyses were made with the IBM SPSS statistics.20 and Sphinx 4 software. Charts were generated with the Excel 2016 Spreadsheet. 


\section{RESULTS}

Profile of farmers in the three agroecological zonesMore than $80 \%$ of the guinea fowl producers encountered were men in the three agroecological zones of Burkina Faso. The breeding of guinea fowl was therefore a male activity in Burkina Faso. In fact, the producers met in the agroecological zones were essentially married (87.17\%) and that more than $60 \%$ had agriculture as their main activity. In addition, over $80 \%$ of producers had received no training in guinea fowl breeding. For the level of education, the majority of breeders surveyed in northern Sudan had no level of education. On the other hand, in Southern Sudan the majority had primary education and in the Sahel the majority of the producers were educated in the Koranic school. Concerning the question of religion, Fig. 2 shows the religion of the producers according to the agroecological zones in Burkina Faso. Chi-square statistical analysis revealed a moderately significant difference at the $0.5 \%$ level $(p<0.005$ and $\mathrm{Cr}<0.70)$ of religions between the three ecotypes. Unlike northern Sudan, Muslims dominate in southern Sudan and the Sahel.

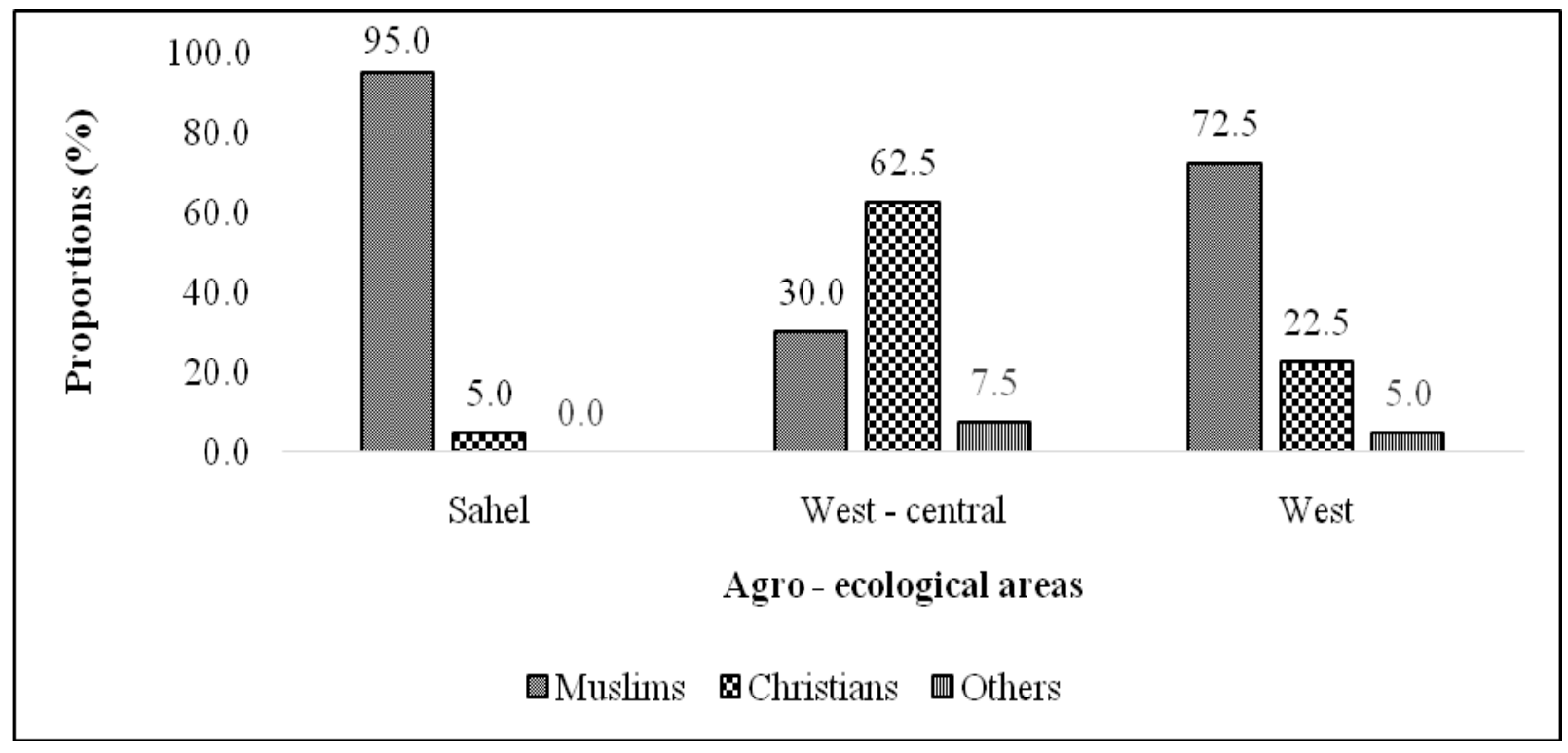

Fig. 2: Producers religion in Burkina Faso

Farms of local guinea fowl (N. meleagris)- The appreciation of Guinea Fowl Farming industry by the producers is mentioned in Table 1 . We must remember that the breeders were motivated on the one hand because of the economic profitability of the activity, the quality of the meat and the ease of the guinea fowl on sale; on the other hand, the motivation of the farmers was related to its immediate adaptation of the environment, the cultural aspect, the high productivity. There were other types of motivation (the guinea fowl's docility, hardiness, and passion etc).

Table 1: Appreciation of the Guinea Fowl farming industry by the producers

\begin{tabular}{lllll}
\hline \multirow{2}{*}{ Appreciation } & \multicolumn{2}{c}{ Agroecological areas } & Average \\
\cline { 2 - 5 } & Sahel & West-central & West & 46.7 \\
\hline Adaptation of the environment & 37.5 & 15 & 87.5 & 1.7 \\
Docility & 0 & 5 & 0 & 10.8 \\
Rusticity & 5 & 27.5 & 0 & 25.8 \\
Facility breeding & 40 & 20 & 17.5 & 34.2 \\
Productivity & 32.5 & 12.5 & 57.5 & 83.3 \\
Economic profitability & 90 & 60 & 100 &
\end{tabular}




\section{Quality of the meat}

Facility of the sale

Culturel/Tradition

Passion

$\begin{array}{ll}67.5 & 37.5 \\ 87.5 & 32.5 \\ 72.5 & 45 \\ 2.5 & 0\end{array}$

37.5
97.5

82.5

2.5

0
67.5

67.5

40

0.8
Mode of acquisition of guinea fowl and the origin of the first breeders- The method of obtaining the first breeders at startup was mainly based on the purchase of eggs for brooding and donating eggs for brooding. Others have obtained it either by family inheritance or by the purchase of breeding stock. It should be noted that the first breeders generally come from their regions and/or neighboring villages but sometimes from other regions or villages far from their own.

Breeding methods, breeds, habitats- In the agroecological zones of Burkina Faso, the guinea fowl breeding system was mainly the traditional/extensive mode; this was met more than $90 \%$ in all three ecotypes. The semi-intensive mode was also met but in a minority way. As for the breed, all guinea fowl encountered were
$100 \%$ native/local breeds. In the north and south of Sudan, traditional hen houses were mainly found $72.5 \%$ and $52.5 \%$ respectively while in the Sahel, the majority does not have a habitat to shelter the guinea fowl was $47.5 \%$. Modern hen houses were found in minority areas in these areas. In the Sahel, cages were found at $10 \%$.

Types of production, destination and reasons for harvesting guinea fowl and eggs- In the agroecological zones of Burkina Faso, guinea fowl production was based on the marketing of live guinea fowl and eggs. Others produce them for the flesh and for many others. The types of production are shown in Table 2.

Table 2: Types of production of the Sahel, West-central and West-ecotypes of guinea fowls in Burkina Faso

\begin{tabular}{lllll}
\hline \multirow{2}{*}{ Type of production } & \multicolumn{3}{c}{ Agro-ecological areas } \\
\cline { 2 - 4 } & Sahel & West-central & West \\
\hline Marketing of live guinea fowl & 90 & 95 & 95 & 93.3 \\
Eggs & 82.5 & 87.5 & 100 & 90 \\
Meat & 2.5 & 2.5 & 2.5 & 2.5 \\
Others & 10 & 05 & 0 & 05 \\
\hline
\end{tabular}

With regards to the destination of guinea fowl and eggs, the majority of producers claimed that it was essentially self-consumption (95\% for guinea fowl and $99.2 \%$ for eggs), for sale $(96,7 \%$ for guinea fowl and $92.5 \%$ for eggs), for the reproduction of guinea fowl (98.3\%) and hatching of eggs (99.2\%) and donations (95\% for guinea fowl and $93.3 \%$ for eggs). Some also speak of the exchange aspect and the cultural aspect (1.2\%).

For farmers, the samples were taken mainly for the purpose of feeding the families (95\% for eggs and $96.7 \%$ for guinea fowl), cash (89.2\% for eggs and $91.7 \%$ for guinea fowl), maintenance of relationships and social cohesion (87.5\% for eggs and $92.5 \%$ for guinea fowl) and many others such as schooling, pharmaceuticals, etc. (5\%).
Proportion of use of guinea fowl and eggs- In the agroecological zones of Burkina Faso, $45 \%$ of producers reserved 2 to 4 guinea fowl out of 10 for breeding. This proportion was mostly found in the northern Sudan area (72.5\%). In the Sahel and southern Sudan, however, 4-6 guinea fowl were reserved for breeding respectively $47.5 \%$ and $67.55 \%$. Thus 4 to 6 guinea fowl were generally reserved for sale (45\%) overall. Only one guinea fowl out of 10 was usually reserved for selfconsumption, donations, trade respectively $70 \%, 76.8 \%$, $23.3 \%$ of producers.

Like guinea fowl, $60.8 \%$ of producers reserve 2 to 4 eggs out of 10 for brooding. This proportion was mainly found in the northern Sudan zone (60\%) and Sahel (85\%). 
In southern Sudan, however, the majority of producers (55.5\%) reserve 4 to 6 eggs out of 10 for brooding. Thus 2 to 4 eggs out of 10 were generally reserved for sale (54.2\%) overall.

Prices of guinea fowl, eggs and places of sale- In the agroecological zones of Burkina Faso, the price of the egg varies from 40 to 100 FCFA. According to the melee farmers ( $84.2 \%$ on average), the price of the best-known egg went from 50 to 75 FCFA. Regarding the price of guinea fowl, it varies from 2000 to 4000 FCFA and does not vary according to the types of plumage. But the price of white guinea fowl was generally higher than that of other types of plumage. According to the agro-farmers (59.2\% on average), the best known price for guinea fowl ranges from 2500 to 3000 FCFA but in large cities like Bobo Dioulasso and Ouagadougou, for example, white guinea fowl generally range from 3500 to 4000 FCFA. It should be noted that in Burkina Faso, the price of guinea fowl was not gender-based and that sales were mostly at home, on the farm, at the sector or village market and other markets such as nearest big cities.

Main constraints in the guinea fowl production chainThe main constraints related to the breeding of guinea fowl were diverse. They were technical, sanitary, food and commercial. In Burkina Faso, guinea fowl were reared under precarious technical conditions. Indeed, the lack of habitat, drinker, feeder, nest, food; problems (health, predation, hatching, and space), mortalities, slow growth, low productivities, theft and others were constraints reported by farmers in agro-ecological zones. The five major constraints were discussed in Fig. 3.

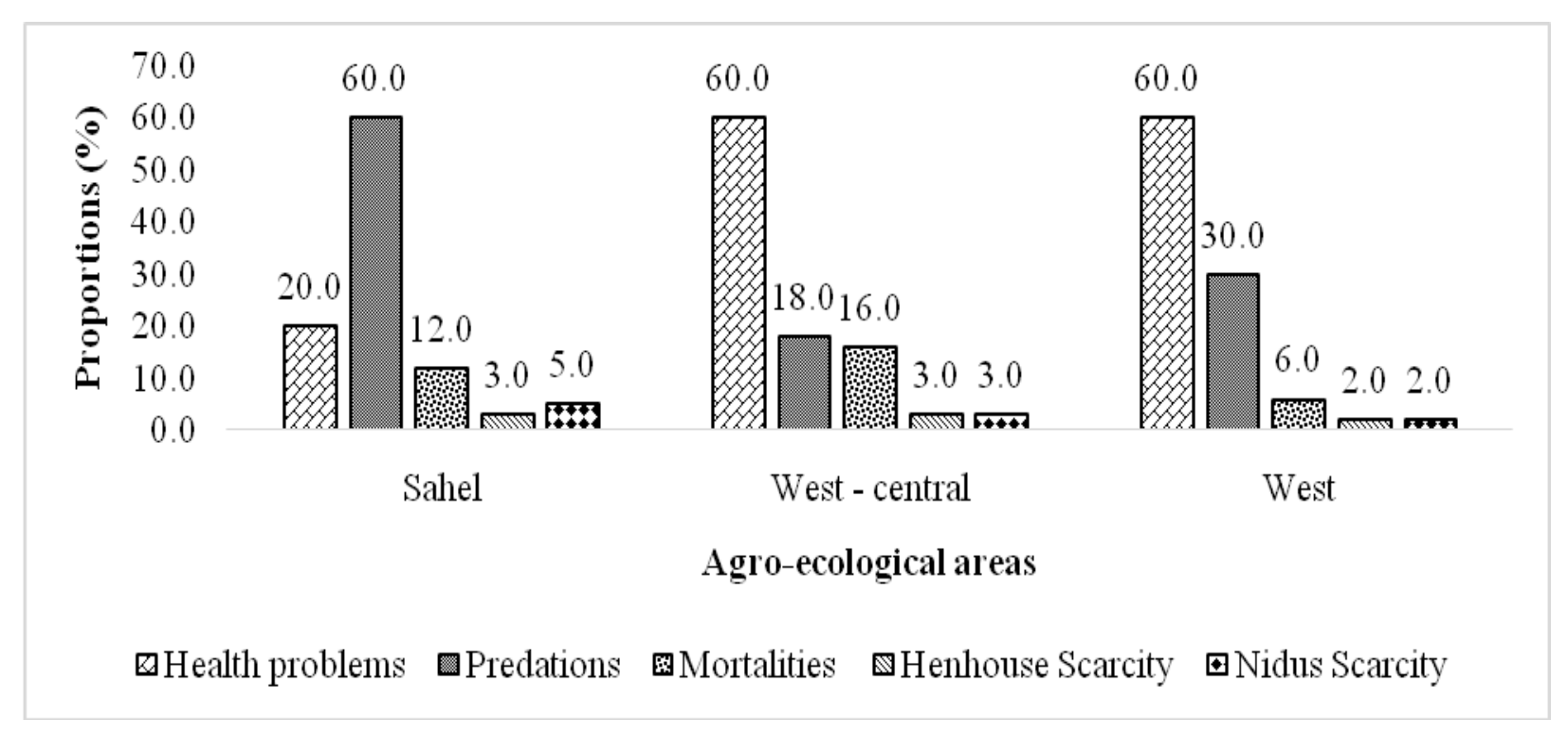

Fig. 3: Majors constraints of Guinea fowl breeding in Burkina Faso

These constraints were quoted in approximately the same proportions in the three agroecological zones, but the problems of predation and nests were mainly found in the Sahel, respectively $97.5 \%$ and $60 \%$. In the Sahel, guinea fowl were very at risk because there were not enough trees and shrubs to allow animals to protect themselves from predators. Sanitary management of Guinea Fowl Farming was poor in the three agroecological zones of Burkina Faso. The health status of the guinea fowl is presented in Table 3.

The main signs of diseases encountered in the three agroecological zones of Burkina Faso are diarrhea, worms (internal parasites), insects/lice (external parasites), smallpox, drowsiness, loss of appetite, diarrhea weight loss, scab/ringworm and others (paralysis, hard crop, lower wings, tremors, depressed wings, coughing, sudden death).

Food and trade constraints related to Guinea Fowl farming- The dietary constraints were essentially related to the availability of aliments (59.2\%), the costliness of aliments $(83.3 \%)$, and the absence of specific ration (64.2\%). The results are mentioned in Table 4. 
Table 3: Sanitary management of Guinea Fowl Farming in the three agroecological zones of Burkina Faso

\begin{tabular}{|c|c|c|c|c|c|}
\hline \multirow{3}{*}{ Agro-ecological areas } & \multicolumn{2}{|c|}{ Method of prevention } & \multicolumn{2}{|c|}{ Curative treatment } & \multirow[b]{2}{*}{ Pharmacopoeia } \\
\hline & \multirow{2}{*}{ Modalities } & \multirow{2}{*}{$\%$} & \multirow{2}{*}{ Modalities } & Veto & \\
\hline & & & & $\%$ & $\%$ \\
\hline \multirow{6}{*}{ Sahel } & None & 82.5 & None & 77.5 & 97.5 \\
\hline & Vaccination & 12.5 & Internal deparasitage & 22.5 & 0 \\
\hline & Veto-treatment & 17.5 & External deparasitage & 22.5 & 0 \\
\hline & Pharmacopoeia & 0 & Vitamin & 15 & 0 \\
\hline & Habitat hygiene & 2.5 & Antibiotics & 7.5 & 0 \\
\hline & Equipement hygiene & 2.5 & Others & 0 & 2.5 \\
\hline \multirow{6}{*}{ West central } & None & 12.5 & None & 5 & 0 \\
\hline & Vaccination & 45 & Internal deparasitage & 82.5 & 70 \\
\hline & Veto treatment & 60 & External deparasitage & 15 & 15 \\
\hline & Pharmacopoeia & 40 & Vitamin & 30 & 22.5 \\
\hline & Habitat hygiene & 5 & Antibiotics & 60 & 95 \\
\hline & Equipement hygiene & 2.5 & Others & 10 & 2.5 \\
\hline \multirow{6}{*}{ West } & None & 60 & None & 65 & 70 \\
\hline & Vaccination & 22.5 & Internal deparasitage & 17.5 & 2.5 \\
\hline & Veto treatment & 10 & External deparasitage & 17.5 & 2.5 \\
\hline & Pharmacopoeia & 15 & Vitamin & 12.5 & 0 \\
\hline & Habitat hygiene & 12.5 & Antibiotics & 5 & 5 \\
\hline & Equipement hygiene & 12.5 & Others & 17.5 & 30 \\
\hline \multirow{6}{*}{ Average } & None & 51.7 & None & 49.2 & 55.8 \\
\hline & Vaccination & 26.7 & Internal deparasitage & 40.8 & 24.2 \\
\hline & Veto treatment & 29.2 & External deparasitage & 18.3 & 5.8 \\
\hline & Pharmacopoeia & 18.3 & Vitamin & 19.2 & 7.5 \\
\hline & Habitat hygiene & 6.7 & Antibiotics & 24.2 & 33.3 \\
\hline & Equipement hygiene & 5.8 & Others & 9.2 & 11.7 \\
\hline
\end{tabular}

Table 4: Dietary constraints of Guinea Fowl Farming in the three agroecological zones of Burkina Faso

\begin{tabular}{lllll}
\hline \multirow{2}{*}{ Diettaryconstraints } & \multicolumn{3}{c}{ Agro-ecological areas } & Average \\
\cline { 2 - 5 } & Sahel & West-central & West & \\
\hline Availability of aliments & 75 & 75 & 27.5 & 59.2 \\
Costliness of aliments & 72.5 & 87.5 & 90 & 83.3 \\
Absence of specific ration & 100 & 12.5 & 80 & 64.2 \\
Others & 2.5 & 0 & 7.5 & 3.3 \\
\hline
\end{tabular}


The majority of farmers (97.5\%) practice supplementation. The distribution period was morning, noon and evening. It was in the morning that it was frequently practiced. This supplementation was based mainly on cereals, termites, and others. All categories were concerned but keets were given priority. Regarding the flow of eggs and guinea fowl, the majority of farmers said that there were no constraints.

Local knowledge to share: age and gender recognition criteria for guinea fowls- In Burkina Faso, the best known age of sex for guinea fowl was 2 to 4 months. Sometimes you have to wait 4 to 10 months to make the distinction. Some manage to distinguish sex in less than 2 months. The criteria of distinction were the form (ridges, heads, and barbels) the behaviors, the size of the legs. In fact, ridges and barbels were more developed in males than in females. Barbels were open in males and closed in females. Heads were larger in males than females. Legs were longer in males than females, so females were lower than males.

\section{DISCUSSION}

Profile of farmers in the three agroecological zones- In the three agroecological zones, guinea fowl farming has been recognized as a male activity at more than $80 \%$. These results were consistent with those of Sanfo et al. [5]; Seydou [9], which would justify this situation by the fact that there were sometimes conflicts between breeders and the older men especially would be better able to settle amicably the conflict situations. And this lack of training was justified by the lack of interest given to the breeding of guinea fowl by the breeders themselves on the one hand and the technical services on the other hand that focused on the chicken during different sessions of training.

Farms of local guinea fowl (N. meleagris)- According to the breeders, raising guinea fowl in Burkina Faso was economically profitable. Its meat was in quality then the guinea fowl adapts immediately to the environment in which was introduced, it has a cultural aspect. This confirms the results of Sanfo et al. ${ }^{[10]}$, which showed that the sale of eggs and guinea fowls provides income to breeders and resellers.

Breeding methods, breeds, habitats- The breeding of guinea fowl ( $N$. meleagris) was widespread in the three agroecological zones in a traditional system, where it was bred in freedom. It has not yet improved. This situation was due to the hardiness of the local guinea fowl. These results were similar to those of Boko et al. ${ }^{[1]}$; Sanfo et al. [11]; Dahouda [12]; Moreki and Seabo ${ }^{[13]}$; Obike et al. ${ }^{[14]}$, which stipulated that guinea fowl were raised in most West African countries in an extensive system in which several varieties of guinea fowl were raised for meat and eggs.

Types of production, destination and reasons for harvesting guinea fowl and eggs- The guinea fowl production objective was based on the marketing of guinea fowl and eggs in order to ensure selfconsumption and satisfy needs through sales. These results corroborate those of Houndonougbo [15], which showed that the production objectives of farmers were primarily meat and eggs. For self-consumption, 50\% of farmers reserve two out of 10 eggs in Burkina Faso and only one egg out of 10 was generally reserved for donations, the exchanges respectively $62.5 \%, 14.2 \%$ of producers. These results corroborate those of Sanfo et al. ${ }^{[5]}$; Diabate ${ }^{[16]}$, who had shown that traditional poultry farming was generally based on the exploitation of small numbers of local poultry.

Main constraints in the guinea fowl production chainThe results obtained were consistent with those of Boko et al. ${ }^{[1]}$; Sanfo et al. ${ }^{[5]}$; Dahouda et al. ${ }^{[17]}$, which shown that the guiding system in which local guinea fowl were raised in Africa exposes guinea fowl to climatic hazards, diseases, predators and malnutrition according to the seasons which significantly affected their productivity.

The main signs of diseases encountered in the three agroecological zones of Burkina Faso were diarrhea, worms (internal parasites), insects/lice (external parasites), smallpox, drowsiness, loss of appetite, diarrhea weight loss, scab/ringworm and others (paralysis, hard crop, lower wings, tremors, depressed wings, coughing, sudden death). This situation was explained by the fact that producers did not know the sanitary products specific to their animals. Boko et al. ${ }^{[1]}$ explained these results by the fact that the environment has an effect on the health of guinea fowl and this characterized by microbism richly supplied with ecto-parasites, gastro-intestinal parasites, bacteria and viruses in village farms that host several animal species with cross pathologies at a time. The majority of guinea fowl producers (97.5\%) practice supplementation. But 
here the notion of complementation was in the broad sense that was to say that the food was distributed without standards. This was in accordance with the results of Sanfo et al. ${ }^{[5]}$; Dahouda et al. ${ }^{[18]}$, which showed that in this system of free-range farming, food supplementation was often absent and that breeders generally give a few handfuls of cereals and fragments of termite mounds to animals.

\section{CONCLUSIONS}

This study has made it possible to characterize the local guinea fowl ( $N$. meleagris) at the socioeconomic level in the three agroecological zones (Sahelian zone, Sudanese North and South Sudan) of Burkina Faso raised in an uncontrolled environment. The absence of food rations and the non-attendance of veterinary services, the lack of control of production techniques by livestock farmers in production areas is a hindrance to the development of Guinea Fowl Farming in Burkina Faso despite its economic profitability and its great social role.

In view of all the results obtained in this study, our future research will focus on a disease susceptibility and variety stress study that can be used in breed improvement programs to improve productivity; the establishment of a genetic improvement program by selecting local varieties encountered in Burkina Faso to improve their productivity; the organization and training breeders to better ensure dissemination of selected varieties and the establishment of an organization and a control system for the food and health sector of local guinea fowl ( $N$. meleagris).

\section{ACKNOWLEDGMENTS}

The authors wish to acknowledge the technical assistance rendered by Dr. Ollo Cherubin Hien and animal health laboratory of Dr. Gaston Marie Adrien Belem during this study.

\section{CONTRIBUTION OF AUTHORS}

Research concept- Kalo Amadou Ouattara, Dr. Ollo Cherubin Hien, Dr. Gaston Marie Adrien Belem

Research design- Kalo Amadou Ouattara, Dr. Ollo Cherubin HIEN, Dr. Gaston Marie Adrien Belem

Supervision-Dr. Ollo Cherubin Hien, Dr. Gaston Marie Adrien Belem

Materials- Dr. Ollo Cherubin Hien, Dr. Gaston Marie Adrien Belem, Issa Dao

Data collection- Kalo Amadou Ouattara, Dr. Ollo Cherubin Hien, Dr. Gaston Marie Adrien Belem, Issa Dao
Data analysis and Interpretation- Kalo Amadou Ouattara, Dr. Ollo Cherubin Hien, Dr. Gaston Marie Adrien Belem

Literature search- Kalo Amadou Ouattara, Dr Ollo Cherubin Hien, Dr. Gaston Marie Adrien Belem

Writing article- Kalo Amadou Ouattara, Dr. Ollo Cherubin Hien, Dr. Gaston Marie Adrien Belem

Critical review-Dr. Ollo Cherubin HIEN, Dr. Gaston Marie Adrien Belem

Article editing- Kalo Amadou Ouattara, Dr. Ollo Cherubin Hien, Dr. Gaston Marie Adrien Belem

Final approval- Kalo Amadou Ouattara, Dr. Ollo Cherubin Hien, Dr. Gaston Marie Adrien Belem

\section{REFERENCES}

[1] Boko KC, Kpodekon TM, Dahouda M, Marlier D, Mainil JG. Technical and health constraints of traditional guinea fowl production in sub-Saharan Africa. Ann. Rech. Vet., 2012; 156: 25-36.

[2] Issoufou AD. Morphobiometric and molecular characterization of local populations of Guinea fowl N. meleagris from Niger. Diploma in Advanced Studies in Integrated Natural Resource Management, IDR/UPB, 2016; pp. 42.

[3] Houdonougbo PV, Chrysostome AAC, Houndonougbo MF, Bindelle J, Gengler N. Evaluation of the quality of external and internal eggs of five varieties of local guinea fowl raised in Benin. Rev. Cames, 2014; 2 (2): 2424-35.

[4] Laurenson P. Determination of the zootechnical parameters of the local guinea fowl in the region of Borgou (Engineer's memory). Faculty of Agronomic Sciences of Gembloux: Gembloux, 2002; pp. 81.

[5] Sanfo R, Boly H, Sawadogo L, Ogle B. Characteristics of the village breeding of the local guinea fowl (Numida meleagris) in central Burkina Faso. Tropicultura, 2007; 25(1): 31-36.

[6] Houndonougbo PV. Morphological characteristics and growth performance of the different varieties of local guinea fowl raised in Benin. Graduation work prior to the PhD in Agronomic Sciences. University of Liege. Gembloux Agro Bio Tech., Gembloux, Belgium, 2011; pp. 80.

[7] Sanfo R, Boly H, Sawadogo L, Ogle B. Elements of analysis of the village breeding of the local guinea fowl (Numida meleagris) in the Central Plateau of Burkina Faso. Afr. J. Anim. Health Prod., 2009; 7: 107-14. 
[8] Halbouche M, Didi M, Bourezak N, Lamari S. Performance of Ponte, Reproduction and Growth of the Guinea Fowl (N. Meleagris) in Algeria. Eur. J. Sci. Res., 2010; 47 (3): 320-33.

[9] Seydou A. Supply analysis of the city of Niamey (Niger) of poultry farmyard. Master's thesis in animal production and sustainable development, Cheick Anta Diop University in Dakar, 2012; 5: 31.

[10]Sanfo R, Ouoba-Ima S, Salissou I, Tamboura HH. Etude comparative de l'exploitation traditionnelle de la pintade locale (Numida meleagris) dans deux villages, Toeghin et Sambonaye, au Burkina Faso. IJBCS, 2014; 8(4): 1493-1503.

[11]Sanfo R, Boly H, Sawadogo L'Ogle B. Weight performances of the local guinea fowl (N. meleagris) as an improved feeding system in the central zone of Burkina Faso. Livestock Vet. Medicine J. Trop. Countries, 2008; 61 (2): 135-40.

[12]Dahouda M. Contribution to the study of the diet of the local guinea fowl in Benin, and prospects for improvements using unconventional resources. PhD thesis in veterinary sciences. University of Liege, 2009; pp. 170.

[13]Moreki JC, Seabo D. Guinea Fowl Production in Botswana. J. World Poult. Res., 2012; 2(1): 01-04.
[14]Obike OM, Oke UK, Azu KE. Phenotypic correlations among body weight, external and internal egg quality traits of pearl and black strains of guinea fowl in humid tropical environment J. Anim. Sci. Adv., 2012; 2(10): 857-64.

[15]Houndonougbo PV. Phenotypic characterization of local Guinea fowl (N. meleagris) populations in Benin. Doctoral Thesis (PhD). University of Liege, Gembloux Agro-Bio Tech (Belgium), 2017; pp. 130.

[16]Diabate H. Traditional breeding of guinea fowl in Upper Volta. Submission submitted for the Diploma of Rural Development Engineer, ISP Ouagadougou, UO, Burkina Faso, 1981; pp. 109.

[17]Dahouda M, Senou M, Toleba SS, Boko CK, Adandedjan JC, Hornick JL. Comparison of the production characteristics of the local guinea fowl ( $N$. meleagris) at the station and in the village environment in the Sudano-Guinean zone of Benin. Livestock Res. Rural. Dev., 2008; 20: 12.

[18]Dahouda M, Toleba SS, Youssao AK, BaniKogui S, Aboubakari Y, Hornick JL. Constraints to the breeding of guinea fowl and composition of herds in the traditional farms of Borgou in Benin. Int. Network Dev. Fam. Poult., 2007; 17: 03-14.

\section{Open Access Policy:}

Authors/Contributors are responsible for originality, contents, correct references, and ethical issues. SSR-IIJLS publishes all articles under Creative Commons Attribution- Non-Commercial 4.0 International License (CC BY-NC). https://creativecommons.org/licenses/by-nc/4.0/legalcode (c) $)(i)$ 